\title{
THE EFFECT OF PRODUCT QUALITY, FEATURES, WORD OF MOUTH AND E-COMMERCE ON PURCHASE DECISIONS
}

\author{
Shochibul Mighfar \\ Sukaris \\ Moch. Saleh
}

Ahmad Qoni Dewantoro

Management Study Program - Faculty of Economics and Business, Universitas Muhammadiyah Gresik

Author Correspondance:

Sukaris

Sukaris21@umg.ac.id

\begin{abstract}
ABSTRAK
Penelitian ini bertujuan untuk menguji Pengaruh Kualitas Produk, Fitur, Word of Mouth dan Ecommerce terhadap keputusan pembelian smartphone Xiaomi. Jenis penelitian ini adalah penelitian kuantitatif. Teknik pengambilan sampel menggunakan teknik accidental sampling dengan jumlah sampel 100 konsumen yang tergabung dalam aplikasi komunitas MI. Untuk menganalisis hubungan antara variabel dependen dan independen adalah regresi linier berganda dengan uji asumsi klasik (uji normalitas, uji multikolinieritas, dan uji heteroskedastisitas), uji hipotesis (uji t dan uji F), serta uji model (uji koefisien determinasi). Hasil uji $t$ menunjukkan bahwa kualitas produk dan fitur berpengaruh terhadap keputusan pembelian smartphone Xiaomi dengan tingkat signifikansi $(0,000$ dan 0,005), word of mouth dan e-commerce tidak berpengaruh pada smartphone Xiaomi dengan tingkat signifikansi $(0,311$ dan 0,568). ). Hasil simultan dengan uji $F$, kualitas produk, fitur, word of mouth dan e-commerce secara simultan berpengaruh terhadap keputusan pembelian smartphone Xiaomi. Koefisien determinasi menunjukkan nilai Adjusted $R$ Square sebesar 0,974 sehingga kualitas produk, fitur, word of mouth dan e-commerce dapat dijelaskan oleh variabel bebas sebesar 97,4\%, sedangkan sisanya dijelaskan oleh faktor lain.
\end{abstract}

Kata Kunci: Kualitas Produk, Fitur, Word of Mouth, E-commerce, Keputusan Pembelian.

\begin{abstract}
This study aims to examine the Effect of Product Quality, Features, Word of Mouth and E-commerce on Xiaomi smartphone purchasing decisions. This type of research is quantitative research. The sampling technique uses accidental sampling technique with a total sample of 100 consumers who are members of the MI community application. To analyze the relationship between dependent and independent variables is multiple linear regression with classic assumption test (normality test, multicollinearity test, and heteroscedasticity test), hypothesis test (t-test and $F$ test), and also model test (test coefficient of determination). The results of the $t$-test indicate that product quality and features influence the Xiaomi smartphone purchase decision with a significance level $(0,000$ and 0.005), word of mouth and e-commerce have no effect on Xiaomi smartphones with a significance level (0.311 and 0.568). Simultaneous results with the $F$ test, product quality, features, word of mouth and e-commerce simultaneously influence the purchase decisions of Xiaomi smartphones. The determination coefficient shows that the Adjusted $R$ Square value is 0.974 that product quality,
\end{abstract}


features, word of mouth and e-commerce can be explained by the independent variable of $97.4 \%$, while the rest is explained by other factors.

Keywords: Product Quality, Features, Word of Mouth, E-commerce, Purchasing Decisions.

\section{INTRODUCTION}

Era digitizing this time has affected patterns of consumption and consumer spending ways, from conventional transaction switch to digital. The development of information technology has also undergone substantive changes in the formation of consumer behaviour. With the internet, opportunities for consumers to make purchases become wider through various access to products or services and increase the ease of making purchases as stated by Sukaris et al., (2019) that technological advances through various media platforms both print, electronic, digital media and social media contributes to shifting consumer consumption patterns.

The rapid development of smartphones is marked by the level of competition between companies that are getting tighter. The fenome has ultimately had a major impact on media change, which has led to changes in views, concepts and orientations, in other fields including communication such as e-WOM, ebusiness and e-marketing. From a marketing perspective, new perspectives and modern market concepts that are market-oriented or consumer-oriented, it is the electronic market. Meanwhile, from a business perspective, it creates new views and concepts called digital marketing. Now the interaction model has developed towards electronic interaction or modern e-commerce. One form of business and marketing activities that apply the concepts of electronic markets, digital marketing, and e-commerce which are currently prevalent is the online store business (Hartini et al., 2020)

Various kinds of companies have sprung up offering smartphones with various attractive features and designs for consumers. This development can be seen from the increase in global smartphone sales in the first quarter of 2018, smartphone sales rose 1.3 percent from the same period last year with a total sales volume of 384 million smartphones (Tekno.Kompas.com, July 10 2018). This is in line with the increasing market demand because according to Emarketer data, active smartphone users in Indonesia from 2013-2017 continued to increase, namely from 27,4 million in 2013, 3, 3, 3, 3 million in 2014 , 52.2 million in $2015,69.4$ million in 2016, and 86.6 million in 2017 (id.techinasia.com, 12 July 2018 ). BPS data also mentioned that the number of Indonesian population in 2016 is 25, 7, 9 million people. With population growth of $1.49 \%$ per year, certainly, the demand for smartphones will also increase.

Several factors that influence sales include Product Quality. M According to Kotler and Armstrong (2012; 64 ) is the ability of a product to demonstrate its functions, it includes the overall durability, reliability, accuracy, ease of operation and repair products as well other product attributes. The quality of the product is one of the determinants of the level of purchasing representatives of a product. Quality products for consumers are products that provide value, and from the value obtained, consumers will carry out behavioural activities, both purchasing, loyalty and recommendations to others (Sukaris et al ., 2019)

After considering product quality, consumers also consider the features. According to Kotler and Armstrong (2014; 254), Features are tools to compete that differentiate a company's products from other companies. Features are a competitive means of differentiating a company's products from competitors' products. To meet the satisfaction 
level of consumer needs and desires is to own a product, use, and utilize the product. Product features include hardware and software. Hardware is a description of a physically touchable device. The hardware of a smartphone is the body of the phone itself, size and weight. Colour and design are also considered as hardware because of the physical appearance of the Smartphone. While the software is a general term for operating systems and applications that run on smartphones. Kotler and Armstrong (2014; 254) state that indicators for product features are feature diversity, feature quality, feature completeness, and feature importance. The features contained in Xiaomi smartphones are also important as determining the level of product purchase decisions.

The factor of word of mouth also influences purchasing decisions, word of mouth communication (WOM) or word of mouth is a communication process in the form of providing recommendations both individually and in groups of a product or service that aims to provide personal information ( Kotler and Keller, 2012; 136). Sukaris, et al., (2020) stated that WOM can be related to the purchasing experience and plays an important role in reducing risk and has been considered important for businesses as a substitute for advertising.

The influence of someone in word of mouth is very strong because consumers generally respect their friends and are relatively trustworthy and trusted than commercial sources of information.

The factor of E-commerce also affects the purchasing decision for Xiaomi smartphones. Xiaomi is a smartphone brand which is a newcomer to the smartphone industry. As a newcomer, Xiaomi should have used a marketing strategy that was superior and more aggressive than companies that were already in the market first, but this was not done by the Xioami manufacturer which was proven especially by the lack of promotions carried out and the use of strategies that were originally only exclusive distribution channels. namely by marketing using an online system. Another sale of Xiaomi smartphones is through the official smartphone distributor in Indonesia "Erafone Jaya", Xiaomi also sells through several e-commerce in Indonesia, one of which is Lazada. E-commerce is the buying, selling and marketing of goods and services through electronic systems. Such as radio, television, and computer networks or the internet. (Wong, 2010; 33) .

According to Kotler and Keller (2012; 166), the purchase decision is "Buying decision is a process all the experiences in learning, choosing, using, and even disposing of a product" which means that purchasing decisions are all experiences in learning, selection, use, and even getting rid of the product.

In connection with the existing background, the researcher is interested in tittle of study "Effect of Product Quality, Features, Word of Mouth and E-commerce Buying Decision Against Smartphone Xiaomi ".

Hypothesis

Based on the background and existing problems, it is directed to refer to the provisional assumptions, namely:

1. Partial effect of Product Quality on purchasing decisions for Xiaomi smartphones.

2. Partial influence of features on purchasing decisions for Xiaomi smartphones.

3. Partial influence of Word of Mouth on purchasing decisions for Xiaomi smartphones.

4. E-commerce influence partially on purchasing decisions for Xiaomi smartphones.

5. Simultaneous influence of Product Quality, Features, Word of Mouth and E-commerce on purchasing decisions for Xiaomi smartphones.

\section{METHODE}

The research approach used in this research is quantitative. The research process is deductive, 
in which to answer the problem formulation, concepts or theories are used.

\section{Population}

In this study, the population of consumers who have bought Xiaomi smartphones through the Lazada application or website and joined the Mi Community Forum

\section{Sample}

According to Ferdinad (2011: 215), the sample is a subset of the population, consisting of several members of the population. The sampling technique in this study is the incidental sampling technique. According to Sugiyono (2010: 124), incidental sampling is a sampling technique based on chance, that is, anyone who accidentally or incidentally meets a researcher can be used as a sample if it is considered that the person who happened to be met is suitable as a data source. The number of samples used by this researcher was 100 respondents.

\section{Data Analysis}

The steps to analyze the data in this study are as follows:

1. Perform calculations for each variable which will be further analyzed in the SPSS program, as shown in the attachment to this study.

2. Perform descriptive analysis of research variables.

3. Perform testing the classical assumptions which consist of the normality test, the multicollinearity test, and the heteroscedasticity test.

4. Perform multiple linear regression analysis.

5. Test the coefficient of determination of $\mathrm{R}^{2}$.

6. Performing hypothesis testing partially ( $\mathrm{t}-$ test) and simultaneously (F test)

\section{RESULTS}

Based on the research and analysis that the researcher processed using the SPSS analysis tool, the researcher could interpret the results as follows:

Partial proof of the regression hypothesis (t-test) is shown to determine the effect of each independent variable consisting of Product Quality, Features, Word of Mouth and E-commerce on the dependent variable, namely purchasing decisions.

Product Quality (X1) obtained a value of $0.000<0.05$ so that Ho was rejected and $\mathrm{Ha}$ was accepted. It can be concluded that the Product Quality variable (X1) is proven to have a significant effect on purchasing decisions for Xiaomi smartphones.

Feature (X2) obtains a value of 0.005 $<0.05$ so that $\mathrm{Ho}$ is rejected and $\mathrm{Ha}$ is accepted. It can be concluded that the feature variable (X2) is proven to have a significant effect on the purchase decision of Grand Shimpoy Gresik Housing.

Word of Mouth (X 3 ) obtained a value of $0.311<0.05$ so that Ho was accepted and $\mathrm{Ha}$ was rejected. It can be concluded that the variable Word of Mouth (X 3 ) does not affect purchasing decisions for Xiaomi smartphones.

E-commerce (X 4 ) obtained a value of $0,568<0.05$, so that Ho was accepted and $\mathrm{Ha}$ was rejected. It can be concluded that the Ecommerce variable ( $\mathrm{X} 4$ ) is proven to not affect purchasing decisions for Xiaomi smartphones.

Quality Products, Features, Word of Mouth and Ecommerce obtain the value of significance of less than 0.05 is 0.000 so that $d$ apat concluded that together significantly influence purchasing decisions Smartphone Xiaomi

\section{CONCLUSION}

Based on the results of data processing in this study, the following conclusions can be drawn: Quality Products effect on partially to established decision to choose Smartphone Xiaomi. Feature effect partially to established decision buys Smartphone Xiaomi. Word of Mouth no effect partially to support decision buy Smartphone Xiaomi. E-commerce no 
effect partially to support decision buy Smartphone Xiaomi and Quality Products, Features, Word of Mouth and E-commerce proved effect be simultaneously against the decision established purchase Smartphone Xiaomi

Based on the results of the analysis, discussion, and research conclusions, the recommendations from the researchers can be given as follows:

Further Research: the results of this study can be used as a reference or support by increasing the number of a wider population so that it can provide an overview of the results that are closer to the actual conditions.

For Companies: To increase Ecommerce while considering the positive and negative impacts. In this case, the company needs to look at e-commerce as a form of company cooperation in selling Xiaomi smartphones and its use so that e-commerce can have a big influence on the company's ability and growth rate.

\section{REFERENCES}

Agustyan, Fajar, 2017, The Effect of Ecommerce, Product Quality and Brand Image on Purchasing Decisions in the Creative Economy Industry, Digilib Unila.

Alma, Buchari, 2013, Marketing Management and Service Marketing, Alfabeta, Bandung.

Dantes, Nyoman, 2012, Research Methods. Andi, Yogyakarta.

Deni Setiawan, 2017, Latest Data The Population of Indonesia Is More Than 262 Million People. http://jateng.tribunnews.com, accessed on 13 March 2018.

Fahmi, Reza Zulfikar, 2016, The Influence of Perceptions of Product Quality, Brand Awareness of Product Features and Prices on Purchasing Decisions of Xiaomi Phones in Surabaya, Perbanas Scientific Article, Surabaya.
Ghozali, Imam, 2012, Multivariate Analysis Application with the IBM SPSS Program, Diponegoro University Publishing Agency, Semarang.

2014, Application of Multivariate Analysis with the SPSS Program, Fourth Edition, Diponegoro University Publishing Agency, Semarang.

2016, Application of Multivariate Analysis with the IBM SPSS 23 Program, Eighth Edition, Diponegoro University Publishing Agency, Semarang.

Gujarati, DN, 2012, Basics of Econometrics, Salemba Empat, book 2, 5th Edition, Jakarta.

Hartini, S., Mardhiyah, D. and Sukaris (2020) 'A conceptual framework for relationship between symbolic risk consumption with electronic word of mouth', Opcion, 36 (Special Edition 26), pp. 1282-1295.

Hasan, Ali, 2010, Marketing from mouth to mouth, Media Presindo, Yogyakarta.

Katadata, 2018, Lazada, Most E-commerce Visitors for Q1 2018, www.databoks.katadata.co.id accessed on 9 July 2018.

Kharis, Ismu Fadli, 2011, Study of Impulse Buying in Online Sales, Thesis Diponegoro University, Semarang.

Khoirunnisa, 2018, Canalyst top 5 smartphone vendors in Indonesia. https://selular.id, accessed May 22, 2018 at 12.00.

Kotler and Amstrong, 2010, Marketing Principles, Issue 12, Volume 1 and 2, Erlangga, Jakarta.

2012, Marketing Principles, Edition 13 Volume 1, Erlangga, Jakarta. , 2014, Marketing Principles, Edition 15 Volume 1, Erlangga, Jakarta.

Kotler and Keller, 2012, Marketing Management, 12th Edition, Erlangga, Jakarta. 
Kotler, Philip, 2010, Marketing Management, Issue 13, Volume 1 and 2, Erlangga, Jakarta.

Lestari, Gita Putri, 2017, The Effect of Product Quality, Price Perception, Features, and Design on Furniture Purchasing Decisions at MS Vintage Furniture in Jepara, Jurnal dinus.ac.id

Lotulung, Lapian, and Moniharapon, 2015, The Influence of Product Quality, Price, and WOM (Word Of Mouth) on Evercoss Mobile Purchase Decisions at CV. Tristar Jaya Globalindo Manado, Emba Journal, Vol. 3 No.3, 817-826.

Luthfi, Ahmad, 2014, In Indonesia, Smartphones have become a major need, https://techno.okezone.com, accessed on 23 May 2018 at 13.00

Millward, Steven, 2018, Indonesia is projected to exceed 100 million smartphone users in 2018, fourth in the world, https://id.techinasia.com, accessed on 12 July 2018 at 13.00

Pertiwi, Wahyunanda Kusuma, 2018, Global Smartphone Sales Again Positive, One Brand Raising, https://tekno.kompas.com, accessed July 10, 2018, at 13.00.

Putra, Arifin and Sunarti, 2017, The Effect of Product Quality on Purchasing Decisions and Its Impact on Customer Satisfaction, Journal of Business Administration, Vol 48 No1.

Sugiyono, 2010, Qualitative and Quantitative Research Methods R \& D, Alfabeta, Bandung.

2012, Qualitative and Quantitative Research Methods R \& D, Alfabeta, Bandung.

Sukaris, S., Hartini, S., \& Mardhiyah, D. (2020). The effect of perceived value by the tourists toward the electronic word of mouth activity: the moderating role of conspicuous tendency. Journal of Business Strategy, 24 (1), 1-17.

Sukaris, S., Hartini, S. and Mardhiyah, D. (2019) 'Increasing Electronic Word-of-
Mouth Activities through Self-Congruity and Tourist Values', International Journal of Innovation, Creativity and Change, 9 (10), pp. 162-183.

Sumardi et al, 2011, Utilization of SMS as a Teaching Media for Early Reading and Writing in Low Grades (Classroom Action Research on Learning Indonesian in Primary Schools), Journal of Educational Research, Vol 12 No.1 p. 26 Wijaya, Teguh, Aprilia, 2016, Analysis of the Influence of E-commerce Variables (Interface, Navigation, Content, Reliability, and Technical) on Apartment Purchasing Decisions through the AIRBNB Website, Journal of Hospitality and Service Management, Surabaya.

Wong, Jony, 2010, Internet Marketing for Beginners, Elex Media Komputindo, Jakarta 